\title{
Härkäpapusäilörehu lypsylehmien ruokinnassa
}

\author{
Annu Palmio ${ }^{1}$, Auvo Sairanen ${ }^{1}$, Kaisa Kuoppala ${ }^{2}$ Marketta Rinne $^{2}$ \\ ${ }^{1}$ Luonnonvarakeskus, Vihreä teknologia, Halolantie 31 A, 71750 Maaninka, etunimi.sukunimi@luke.fi \\ ${ }^{2}$ Luonnonvarakeskus, Vihreä teknologia, Tietotie 2 C, 31600 Jokioinen, etunimi.sukunimi@luke.fi
}

\section{Tiivistelmä}

Lypsylehmän tärkeimmät valkuaisen lähteet ovat nurmisäilörehu ja vilja, mutta korkean tuotoksen saavuttamiseksi käytetään lisäksi valkuaistäydennysrehuja; yleisimmin rypsiä, josta vain neljäsosa on kotimaista. Yksi mahdollisuus valkuaisomavaraisuuden parantamiseen on palkokasvien hyödyntäminen. Palkoviljojen korjuu kokoviljasäilörehuna on Suomessa monin paikoin viljelyvarmempaa verrattuna siemenkasvuston korjuuseen.

Luke Maaningalla järjestetyssä lypsylehmien ruokintakokeessa tutkittiin kokoviljana korjatun härkäpavun mahdollisuutta toimia ostorypsin korvaajana. Lisäksi tutkittiin härkäpapusäilörehun vaikutusta syöntiin ja tuotokseen nurmisäilörehuun verrattuna. Härkäpapu (lajike Taifun) niitettiin lautasniittokoneella ja säilöttiin pyöröpaaleihin $20 \mathrm{~h}$ esikuivausajan jälkeen käyttäen AIV2Plus-säilöntäainetta 5 1/tonni. Härkäpapusäilörehun raakavalkuaispitoisuus (rv) oli $181 \mathrm{~g} / \mathrm{kg}$ ka ja D-arvo $646 \mathrm{~g} / \mathrm{kg}$. Ensimmäisen niiton nurmisäilörehun vastaavat pitoisuudet olivat $160 \mathrm{~g} / \mathrm{kg} \mathrm{ka}$ ja $687 \mathrm{~g} / \mathrm{kg}$ ka. Kokeessa oli mukana 27 ayrshire- ja holsteinlehmää. Koeasetelma oli toistetut $3 \times 3$ latinalaiset neliöt. Koeruokintoina oli kolme erilaista seosrehua, joissa kaikissa väkirehun osuus oli $40 \%$. Kontrolliseos $(\mathrm{K})$ sisälsi vain nurmisäilörehua ja ohraa. Härkäpapuseoksessa $(\mathrm{H})$ oli härkäpapu- ja nurmisäilörehua (härkäpapusäilörehun osuus $75 \%$ kuivaaineesta) sekä ohraa. Rypsiseoksessa (R) oli nurmisäilörehua, ohraa ja rypsiä. H- ja R-seosten rvpitoisuudet pyrittiin saamaan samoiksi, joten rypsin määrä R-seoksessa oli varsin maltillinen, noin $6 \%$ kuiva-aineesta. Seosten toteutuneet rv- (g/kg ka) ja energiapitoisuudet (MJ ME/kg ka) olivat 140 ja 11,8 (K), 151 ja 11,6 (H) sekä 155 ja 11,7 (R).

H- ja R-ruokinnat lisäsivät lehmien rehunkulutusta, maito- ja energiakorjattua maitotuotosta (ekm) sekä maidon valkuaispitoisuutta K-ruokintaan verrattuna. Kuiva-aineensyönti oli noin 1,5 kg korkeampi $\mathrm{H}$ - ja R-ruokinnoilla verrattuna K-ruokintaan $(\mathrm{p}<0,001)$. Lehmien maitotuotokset olivat 32,0 (K), 33,5 (H) ja $34,1 \mathrm{~kg} / \mathrm{pv}(\mathrm{R}) . \mathrm{H}-$ ja R-ruokintojen välinen ero maitotuotoksissa ei ollut tilastollisesti merkitsevä. Sen sijaan ekm-tuotos oli R-ruokinnalla merkitsevästi korkeampi kuin H-ruokinnalla (36,6 vs. 37,6 kg/pv, $\mathrm{p}=0,028$ ). Paras energian ja typen hyväksikäyttö saavutettiin K-ruokinnalla. H- ja R-ruokintojen välillä ei ollut eroa ravintoaineiden hyväksikäytöissä. Tutkimuksessa tuotosvasteet rv:n saannin lisäykselle olivat hyvät, 3,5 (H) ja 3,7 kg maitoa/kg rv (R).

Valkuaisen lähteenä kokoviljaksi korjattu härkäpapu ei ole aivan rypsin veroinen johtuen sen selvästi pienemmästä ohitusvalkuaisen määrästä. Härkäpapusäilörehu lisää kuitenkin selvästi syöntiä ja tuotosta pelkkään nurmisäilörehuun verrattuna. Palkoviljojen käytössä on myös muita etuja kuten lannoituskustannusten alentuminen ja korkea kuiva-ainesato vain yhdellä korjuulla. Kokoviljana korjattu härkäpapu on potentiaalinen vaihtoehto lypsylehmien rehustukseen korvamaan osan tarvittavasta rypsistä sekä nurmisäilörehusta.

Asiasanat: härkäpapu, valkuainen, lypsylehmä 


\section{Johdanto}

Lypsylehmän tärkeimmät valkuaisen lähteet ovat nurmisäilörehu ja vilja, mutta korkean tuotoksen saavuttamiseksi käytetään lisäksi valkuaistäydennysrehuja. Suomessa yleisimmin käytetty valkuaistäydennysrehu on rypsi, josta vain neljäsosa on kotimaista. Yksi mahdollisuus valkuaisomavaraisuuden parantamiseen on palkokasvien hyödyntäminen. Palkoviljat kuten herne ja härkäpapu ovat yksivuotisia palkokasveja, joista on perinteisesti käytetty siemensato eläinten ruokinnassa. Suomessa palkoviljojen korjuu kokoviljasäilörehuna on monin paikoin viljelyvarmempaa verrattuna siemenkasvuston korjuuseen. Palkoviljojen käyttöön liittyy myös viljelyteknisiä etuja. Palkoviljat monipuolistavat viljelykiertoa, niiden biologinen typensidonta vähentää ostolannoitteiden tarvetta ja niistä saadaan suuri kuiva-ainesato yhdellä korjuukerralla. Kasvusto voidaan korjata nurmirehun korjuukalustolla ja varastoida nurmisäilörehun tavoin. Palkoviljojen säilöntä voi kuitenkin olla nurmirehua haasteellisempaa niiden matalan kuiva-aineen ja suuren puskurikapasiteetin takia.

Palkoviljasäilörehun energia-arvo on tyypillisesti nurmisäilörehua matalampi ja raakavalkuaispitoisuus vastaavasti suurempi. Palkoviljojen kuitupitoisuus on matala, mutta heinäkasveihin verrattuna niissä sulamattoman kuidun (iNDF) osuus on suurempi. Nautojen ruokinnassa palkoviljasäilörehun nurmisäilörehua heikompaa sulavuutta kompensoi usein sen runsaampi syönti. Palkoviljasäilörehua voidaan tarjota naudoille ainoana karkearehuna, mutta lypsylehmien ruokinnassa on järkevää käyttää palkovilja- ja nurmisäilörehun seosta, jotta lehmien energian saanti ja sitä kautta tuotos varmistetaan.

Nurmipalkokasveja kuten apilaa on tutkittu sekä Suomessa että maailmalla jo paljon. Sen sijaan palkoviljasäilörehujen vaikutuksesta lypsylehmien syöntiin ja maitotuotokseen on tehty tutkimuksia hyvin vähän. Osana Euroopan maaseuturahaston rahoittamaa PalkoSavo-hanketta Luonnonvarakeskuksen (Luke, ennen Maa- ja elintarviketalouden tutkimuskeskus) Maaningan toimipaikassa tutkittiin kokoviljana korjatun härkäpavun mahdollisuutta toimia ostorypsin korvaajana lypsylehmien ruokinnassa. Lisäksi tutkittiin härkäpapusäilörehun vaikutusta syöntiin ja tuotokseen nurmisäilörehuun verrattuna.

\section{Aineisto ja menetelmät}

Ruokintakoe suoritettiin Luke Maaningan tutkimuspihatossa 22.9. - 23.11.2014. Kokeessa oli 27 ayrshireja holsteinrotuista lypsylehmää, joista 9 oli ensikoita ja 18 useamman kerran poikineita. Kaikki koelehmät olivat tuotoskauden alkuvaiheessa. Kokeen alkaessa lehmien poikimisesta oli kulunut keskimäärin 70 päivää (keskihajonta 21,0). Koeasetelma oli toistetut $3 \times 3$ latinalaiset neliöt. Lehmät jaettiin kolmeen blokkiin poikimakerran ja alkulypsykauden tuotoksen perusteella. Blokit olivat ensikot, matalatuottoiset usemman kerran poikineet lehmät ja korkeatuottoiset useamman kerran poikineet lehmät. Blokkien sisällä lehmät jaettiin satunnaisesti koeruokinnoille. Kokeessa oli kolme kolmen viikon jaksoa. Jakson kaksi ensimmäistä viikkoa olivat totutuskautta ja tulokset laskettiin kolmannelta viikolta.

Kokeessa käytetyt karkearehut korjattiin Maaningalla kesällä 2014. Härkäpapu (lajike Taifun) kylvettiin 22.5. ja kasvusto niitettiin lautasniittokoneella 14.8. Noin 20 tunnin esikuivausajan jälkeen härkäpapu karhotettiin ja paalattiin Combi-pyöröpaalaimella ilman vastateriä. Käytetyllä korjuuketjulla siementen karisemistappiot olivat vähäiset, mutta sängen pituus jäi paikoitellen korkeaksi. Härkäpapukasvustosta saatu kuiva-ainesato (5500 kg ka/ha) jäi odotettua pienemmäksi. Ensimmäisen sadon timoteinurminata -säilörehu korjattiin 15.6. ja säilöttiin 24 tunnin esikuivatuksen jälkeen laakasiiloon. Molempien karkearehujen säilöntään käytettiin muurahaishappopohjaista säilöntäainetta (AIV 2 Plus) 5 1/tonni tuoretta rehua.

Koeruokintoina oli kolme erilaista seosrehua, joissa kaikissa väkirehun tavoiteltu osuus oli $40 \%$. Kontrolliseos (K) sisälsi vain nurmisäilörehua ja ohraa. Härkäpapuseoksessa $(\mathrm{H})$ oli härkäpapu- ja nurmisäilörehua sekä ohraa. Härkäpapusäilörehun osuus oli $75 \%$ ja nurmisäilörehun $25 \%$ karkearehun kuiva-aineesta. Rypsiseoksessa (R) oli nurmisäilörehua, ohraa ja rypsirouhetta. H- ja R-seosten raakavalkuaispitoisuudet pyrittiin saamaan samoiksi, joten rypsin määrä R-seoksessa oli varsin maltillinen, noin $6 \%$ koko seoksen kuiva-aineesta ja $14 \%$ väkirehun kuiva-aineesta. 
Koelehmät olivat kahdella 24 lehmän osastolla ja saivat edellä mainittuja seosrehuja vapaasti. Seosrehu jaettiin 4-6 kertaa päivässä ruokintapöydällä oleviin vaa'alla varustettuihin rehukuppeihin (Rouhage Intake Control, Insentec, Hollanti). Rehukuppeja oli yksi kahta lehmää kohden. Lehmät lypsettiin kahdesti päivässä lypsyasemalla (SAC, Hollanti).

Lehmien rehunkulutus ja maitotuotos mitattiin päivittäin. Eläimet punnittiin elopainovaa'alla kokeen alussa sekä jokaisen jakson viimeisellä viikolla. Maitonäytteet otettiin jokaisen jakson kolmannella viikolla kahtena peräkkäisenä päivänä sekä aamu- että iltalypsyn yhteydessä. Maitonäytteistä analysoitiin Valion laboratoriossa rasva, valkuainen, laktoosi, urea ja solupitoisuus. Karkearehuista ja väkirehuista otettiin näytteet kunkin jakson viimeisellä viikolla aina seosrehun teon yhteydessä. Saman jakson näytteet yhdistettiin rehukomponenteittain. Rehujen kemialliset koostumukset analysoitiin Luken laboratoriossa Jokioisilla. Härkäpapusäilörehun pepsiinisellulaasiliukoisuus (OMS) muutettiin orgaanisen aineen sulavuudeksi käyttäen puna-apilalle tarkoitettua muuntoyhtälöä (Huhtanen ym. 2006). Rehujen energia- ja valkuaisarvot laskettiin Luken (2015) kuvaamalla tavalla.

Koetulosten tilastolliseen käsittelyyn käytettiin SAS-ohjelmiston MIXED-proseduuria. Mallin kiinteät tekijät olivat ruokinta, blokki ja jakso. Lehmä oli mallissa satunnaisena tekijänä.

\section{Tulokset ja tulosten tarkastelu}

Härkäpapukasvuston kuiva-ainepitoisuus oli niittohetkellä 184 g/kg. Esikuivauksen aikana tulleen sadekuuron takia rehu jäi märäksi ja paaleja avatessa niistä erittyi keskimäärin 22 litraa puristenestettä. Seosrehussa käytetyn härkäpapusäilörehun keskimääräinen kuiva-ainepitoisuus oli $203 \mathrm{~g} / \mathrm{kg}$. Nurmisäilörehun kuiva-ainepitoisuus oli noin $40 \mathrm{~g} / \mathrm{kg}$ korkeampi kuin härkäpapusäilörehun (taulukko 1). Matalasta kuivaainepitoisuudesta huolimatta härkäpapusäilörehun säilönnällinen laatu oli hyvä. Härkäpapusäilörehussa ammoniumtypen osuus kokonaistypestä oli hieman tavoitearvoa (alle $70 \mathrm{~g} / \mathrm{kg} \mathrm{N}$ ) korkeampi. Nurmisäilörehussa taas haihtuvia rasvahappoja oli hieman tavoitearvoa (alle $20 \mathrm{~g} / \mathrm{kg} \mathrm{ka}$ ) enemmän.

Taulukko 1. Koerehujen kemiallinen koostumus ja rehuarvot.

\begin{tabular}{|c|c|c|c|c|}
\hline & Nurmisäilörehu & Härkäpapusäilörehu & Ohra & Rypsi \\
\hline Kuiva-aine, g/kg & 242 & 203 & 880 & 878 \\
\hline Tuhka, g/kg ka & 83,2 & 78,7 & 28,4 & 73,1 \\
\hline Raakavalkuainen, g/kg ka & 160 & 181 & 117 & 380 \\
\hline Raakarasva, g/kg ka & & & 39,5 & 53,1 \\
\hline Raakakuitu, g/kg ka & & & 46,1 & 136 \\
\hline Kuitu $\mathrm{g} / \mathrm{kg} \mathrm{ka}$ & 522 & 424 & 206 & 279 \\
\hline Tärkkelys, g/kg ka & nd & 90,9 & nd & nd \\
\hline D-arvo, $\mathrm{g} / \mathrm{kg} \mathrm{ka}$ & 687 & 646 & & \\
\hline Muuntokelpoinen energia, g/kg ka & 11,0 & 10,3 & 13,4 & 11,5 \\
\hline $\begin{array}{l}\text { Ohutsuolesta imeytyvä valkuainen, } \\
\mathrm{g} / \mathrm{kg} \mathrm{ka}\end{array}$ & 83,9 & 88,6 & 96,4 & 169 \\
\hline Pötsin valkuaistase, $\mathrm{g} / \mathrm{kg} \mathrm{ka}$ & 28,2 & 50,9 & $-27,9$ & 155 \\
\hline Säilörehun syönti-indeksi & 100 & 111 & & \\
\hline \multicolumn{5}{|l|}{ Säilörehujen säilönnällinen laatu } \\
\hline $\mathrm{pH}$ & 4,01 & 4,16 & & \\
\hline Haihtuvat rasvahapot, $\mathrm{g} / \mathrm{kg} \mathrm{ka}$ & 22,4 & 12,3 & & \\
\hline Maitohappo, g/kg ka & 64,1 & 44,0 & & \\
\hline Sokeri, $\mathrm{g} / \mathrm{kg} \mathrm{ka}$ & 20,4 & 92,2 & & \\
\hline Ammoniumtyppi, g/kg N & 43,6 & 71,9 & & \\
\hline
\end{tabular}


Kokeessa käytetty nurmisäilörehu oli sulavuudeltaan ja rv-pitoisuudeltaan normaalia aikaisen ensimmäisen niiton rehua. Härkäpapusäilörehun in vitro D-arvo (sulavan orgaanisen aineen pitoisuus kuivaaineessa) oli selvästi nurmisäilörehua matalampi, mutta huomattavasti korkeampi kuin viimeaikaisissa pässien sulavuuskokeissa härkäpapuvehnäseokselle määritetty D-arvo 595 g/kg ka (Kuoppala ym. 2014). Härkäpapusäilörehun rv-pitoisuus oli $20 \mathrm{~g} / \mathrm{kg}$ ka korkeampi ja kuitupitoisuus (määritetty neutraalidetergenttimenetelmällä) $98 \mathrm{~g} / \mathrm{kg}$ ka pienempi kuin nurmisäilörehun.

Seosrehuista energiapitoisin oli vain nurmisäilörehua ja ohraa sisältänyt K-seos (taulukko 2). Rypsiä sisältäneen R-seoksen toteutunut rv-pitoisuus oli $3 \%$ korkeampi kuin härkäpapuseosrehun. Hruokinnan rv-pitoisuus oli $8 \%$ ja R-ruokinnan $11 \%$ korkeampi kuin K-ruokinnan.

Taulukko 2. Seosrehujen koostumus ja rehuarvot.

\begin{tabular}{lccc}
\hline & $\begin{array}{c}\text { Kontrolliseos } \\
(\mathrm{K})\end{array}$ & $\begin{array}{c}\text { Härkäpapuseos } \\
(\mathrm{H})\end{array}$ & $\begin{array}{c}\text { Rypsiseos } \\
(\mathrm{R})\end{array}$ \\
\hline Kuiva-aine, g/kg & 324 & 295 & 324 \\
Väkirehun osuus, g/kg & 411 & 407 & 410 \\
Raakavalkuainen, g/kg ka & 140 & 151 & 155 \\
Kuitu, g/kg ka & 384 & 347 & 397 \\
Muuntokelpoinen energia, & 11,8 & 11,6 & 11,7 \\
MJ/kg ka & 87,7 & 90,5 & 92,0 \\
$\begin{array}{l}\text { Ohutsuolesta imeytyvä val- } \\
\text { kuainen, g/kg ka }\end{array}$ & 4,78 & 15,3 & 15,2 \\
$\quad$ Pötsin valkuaistase, g/kg ka & & & \\
\hline
\end{tabular}

Lehmien rehunkulutus oli merkitsevästi suurempi H- ja R-ruokinnoilla kuin K-ruokinnalla (taulukko 3). H-seosta lehmät söivät 1,5 ja R-seosta 1,7 kuiva-ainekiloa enemmän kuin K-seosta. Myös aiemmissa tutkimuksissa rypsin (Huhtanen ym. 2011) ja palkokokoviljasäilörehujen (Huuskonen ym. 2014, Markkanen 2014) on havaittu lisäävän nautojen kuiva-ainesyöntiä. Korkeammasta kuiva-aineen syönnistä johtuen energian saanti oli suurempi H- ja R-ruokinnoilla kuin K-ruokinnalla. H- ja R-ruokintojen välillä ei ollut eroa energian saannissa, mutta rv:n saanti oli merkitsevästi ja OIV:n saanti suuntaa-antavasti suurempi Rruokinnalla kuin H-ruokinnalla. Pienimmät rv:n ja OIV:n saannit olivat odotetusti vähän valkuaista sisältäneellä K-ruokinnalla. Pötsin valkuaistase (PVT) oli kuitenkin positiivinen myös K-ruokinnalla, joten voidaan olettaa, ettei typen saanti rajoittanut mikrobivalkuaisen tuotantoa.

Lehmien maitotuotos oli H-ruokinnalla $1,6 \mathrm{~kg}$ ja R-ruokinnalla $2,1 \mathrm{~kg}$ korkeampi kuin $\mathrm{K}$ ruokinnalla. H- ja R-ruokintojen välinen ero maitotuotoksissa ei ollut tilastollisesti merkitsevä. Energiakorjattua maitoa lehmät tuottivat kuitenkin merkitsevästi enemmän R-ruokinnalla kuin H-ruokinnalla. Rruokinnalla ekm-tuotos oli 1,0 kg korkeampi kuin H-ruokinnalla ja H-ruokinnalla ekm-tuotos oli vastaavasti $1,1 \mathrm{~kg}$ korkeampi kuin K-ruokinnalla.

Huhtanen ym. (2011) havaitsivat meta-analyysissään, että rypsiä käytettäessä tuotos nousi keskimäärin 3,4 kg kun rv:n saanti lisääntyi yhden kilon. Tässä tutkimuksessa tuotos nousi rypsiä käytettäessä $3,7 \mathrm{~kg} / \mathrm{kg}$ rv ja härkäpapusäilörehua käytettäessä 3,5 kg/ kg rv, joten tuotosvasteet rv:n saannin lisäykselle olivat molemmilla ruokinnoilla hyvät. Tässä tutkimuksessa rypsin saanti oli varsin maltillinen, keskimäärin $1,4 \mathrm{~kg} / \mathrm{pv}$. Rypsillä saatava tuotosvaste pienenee sen määrää lisättäessä. Rypsin hieman parempi tuotosvaste härkäpapusäilörehuun verrattuna oli todennäköisesti seurausta siitä, että rypsin sisältämästä valkuaisesta suurempi osa on hyvälaatuista ohitusvalkuaista. Härkäpapusäilörehun valkuaisesta peräti $85 \%$ hajoaa pötsissä kun taas rypsin valkuaisesta pötsihajoavaa on noin $60 \%$ (Luke 2015).

Maidon valkuais- ja rasvapitoisuudet olivat varsin korkeat kaikilla ruokinnoilla. Aiemmissa tutkimuksissa ruokinnan rv-pitoisuuden nousu on lisännyt maidon valkuaispitoisuutta (Huhtanen ym. 2011). Tämän tutkimuksen tulokset olivat yhteneviä aiempien havaintojen kanssa. H- ja R-ruokinnoilla maidon valkuaispitoisuus ja valkuaistuotos olivat suuremmat kuin K-ruokinnalla. Numeerisesti maidon rasvapitoi- 
suus oli korkein K-ruokinnalla ja matalin H-ruokinnalla. K- ja R-ruokintojen välillä ero rasvapitoisuudessa ei kuitenkaan ollut tilastollisesti merkitsevä. H-ruokinnan ruokinnan matalammasta rasvapitoisuudesta johtuen rasvatuotokset olivat samat K- ja H-ruokinnoilla.

Rehuannoksen rv-pitoisuuden nousu johtaa yleensä huonompaan typen hyväksikäyttöön (Huhtanen ym. 2008). Sama havaittiin myös tässä tutkimuksessa, sillä typen hyväksikäyttö oli merkitsevästi parempi niukasti valkuaista sisältäneellä K-ruokinnalla kuin H- ja R-ruokinnoilla. H- ja R-ruokintojenkin rvpitoisuudet olivat matalammat kuin tyypillisesti lypsylehmillä, joten kokeessa typen hyväksikäytöt olivat selvästi maamme keskitasoa paremmat (typen hyväksikäyttö keskimäärin 27,5 \%, ProAgria 2015). Paras energian hyväksikäyttö saavutettiin myös K-ruokinnalla. H- ja R-ruokintojen välillä ravintoaineiden hyväksikäytöissä ei ollut eroa.

Tämän kokeen tulokset vastaavat aikaisempaa käsitystä härkäpavusta tehdyn säilörehun tuotantovaikutuksesta verrattuna nurmisäilörehuun. On kuitenkin muistettava, että molempien karkearehulajien sisällä esiintyy myös runsaasti vaihtelua, joten yksittäisen kokeen tulokset riippuvat siitä, millaiset rehut kokeeseen on valikoitunut. Nurmisäilörehujen sulavuuden ja tuotantovaikutuksen lasku kasvun edetessä on hyvin dokumentoitu (ks. esim. Rinne 2000), mutta härkäpapukokoviljasäilörehun laadun kehityksestä ja parhaasta korjuuajankohdasta vasta rakennetaan näkemystä.

Taulukko 3. Ruokinnan vaikutus syöntiin, ravintoaineiden saantiin ja maitotuotokseen.

\begin{tabular}{|c|c|c|c|c|c|c|c|}
\hline & $\mathrm{K}$ & $\mathrm{H}$ & $\mathrm{R}$ & SEM & K vs. H & K vs. $\mathrm{R}$ & H vs. $R$ \\
\hline \multicolumn{8}{|l|}{ Syönti, kg ka/pv } \\
\hline Väkirehu & 8,8 & 9,2 & 9,6 & 0,16 & $* *$ & $* * *$ & $* *$ \\
\hline Säilörehu & 12,0 & 13,1 & 12,9 & 0,21 & $* * *$ & $* * *$ & \\
\hline Kokonaissyönti & 20,8 & 22,3 & 22,5 & 0,36 & $* * *$ & $* * *$ & \\
\hline \multicolumn{8}{|l|}{ Energia ja valkuaisen saanti } \\
\hline $\mathrm{ME}, \mathrm{MJ} / \mathrm{pv}$ & 246 & 259 & 263 & 4,19 & $* * *$ & $* * *$ & \\
\hline $\mathrm{OIV}, \mathrm{g} / \mathrm{pv}$ & 1830 & 2022 & 2071 & 32,2 & $* * *$ & $* * *$ & o \\
\hline Raakavalkuainen, g/pv & 2914 & 3361 & 3482 & 53,6 & $* * *$ & $* * *$ & $*$ \\
\hline \multicolumn{8}{|l|}{ Tuotos } \\
\hline Maito, kg/pv & 32,0 & 33,5 & 34,1 & 0,79 & $* * *$ & $* * *$ & \\
\hline $\mathrm{Ekm}, \mathrm{kg} / \mathrm{pv}$ & 35,5 & 36,6 & 37,6 & 0,80 & $* *$ & $* * *$ & $*$ \\
\hline Rasva, g/pv & 1588 & 1590 & 1664 & 42,7 & & $* *$ & $* *$ \\
\hline Valkuainen, g/pv & 1065 & 1144 & 1175 & 21,1 & $* * *$ & $* * *$ & $\mathrm{o}$ \\
\hline \multicolumn{8}{|l|}{ Pitoisuus maidossa, $\mathrm{g} / \mathrm{kg}$} \\
\hline Rasva & 49,9 & 47,5 & 49,1 & 0,96 & $* *$ & & o \\
\hline Valkuainen & 33,5 & 34,4 & 34,7 & 0,54 & $* *$ & $* * *$ & \\
\hline Laktoosi & 45,7 & 46,3 & 45,7 & 0,26 & $* *$ & & $*$ \\
\hline Urea, mg/dl & 20,5 & 25,2 & 23,6 & 0,75 & $* * *$ & $* * *$ & $*$ \\
\hline \multicolumn{8}{|c|}{ Ravintoaineiden hyväksikäyttö } \\
\hline $\begin{array}{l}\text { Energian hyväksikäyttö, } \\
\text { MJ ME/kg ekm }\end{array}$ & 5,10 & 5,31 & 5,30 & 0,08 & $*$ & $*$ & \\
\hline Typen hyväksikäyttö & 0,36 & 0,34 & 0,33 & 0,004 & $* * *$ & $* * *$ & \\
\hline OIV g/valkuais g & 1,23 & 1,30 & 1,31 & 0,016 & $* * *$ & $* * *$ & \\
\hline
\end{tabular}

$\mathrm{K}=$ kontrolliseos, $\mathrm{H}=$ härkäpapuseos, $\mathrm{R}=$ rypsiseos

SEM=keskiarvon keskivirhe 


\section{Johtopäätökset}

Tässä tutkimuksessa härkäpapusäilörehun nurmisäilörehua heikompaa sulavuutta kompensoi sen runsaampi syönti. Härkäpapusäilörehun käyttö lisäsi energian ja valkuaisen saantia ja sitä kautta tuotosta pelkkään nurmisäilörehuun verrattuna. Rypsiä sisältäneellä ruokinnalla ekm-tuotos oli korkeampi kuin härkäpapusäilörehulla. Valkuaisen lähteenä kokoviljaksi korjattu härkäpapu ei ole aivan rypsin veroinen johtuen sen selvästi pienemmästä ohitusvalkuaisen määrästä. Tämän tutkimuksen perusteella kokoviljana korjattu härkäpapu on kuitenkin potentiaalinen vaihtoehto lypsylehmien rehustukseen korvaamaan osan tarvittavasta rypsistä sekä nurmisäilörehusta.

\section{Kirjallisuus}

Huhtanen, P., Hetta, M. \& Swensson, C. 2011. Evaluation of canola meal as a protein supplement for dairy cows: A review and a meta-analysis. Canadian Journal of Animal Science 91: 529-543.

Huhtanen, P., Nousiainen, J. \& Rinne, M. 2006. Recent developments in forage evaluation with special reference to practical applications. Agricultural and Food Science 15: 293-323

Huhtanen, P., Nousiainen, J., Rinne, M., Kytölä, K. \& Khalili, H. 2008. Utilization and partition of dietary nitrogen in dairy cows fed grass silage-based diets. Journal of Dairy Science 91: 3589-3599

Huuskonen, A., Pesonen, M. \& Honkavaara M. 2014. Palkokasvisäilörehujen vaikutukset sonnien kasvu- ja teurastuloksiin sekä lihan laatuun. Edistystä luomutuotantoon - loppuraportti. Toim. A. Huuskonen. MTT Raportti 175. s. 73-91. http://urn.fi/URN:ISBN:978-952-487-587-5

Kuoppala, K., Rinne, M., Lötjönen, T., \& Huuskonen, A. 2014. Palkokasveja sisältävien kokoviljasäilörehujen rehuarvon tarkentaminen ruokinnan optimoimiseksi. Edistystä luomutuotantoon - loppuraportti. Toim. A. Huuskonen. MTT Raportti 175. s. 37-50. http://urn.fi/URN:ISBN:978-952-487-587-5

Luke 2015. Rehutaulukot ja ruokintasuositukset. Saatavilla: www.luke.fi/rehutaulukot

Markkanen, A. 2014. Hernekaura- ja härkäpapukaurasäilörehu lypsylehmien ruokinnassa. Maisterintutkielma. Maataloustieteiden laitos, Helsingin yliopisto. $35 \mathrm{~s}$.

ProAgria 2015. Maidontuotannon tulosseminaari 2015.

https://www.proagria.fi/sites/default/files/attachment/ruokinta_ja_rehut_2014_huhtamaki_tuija.pdf

Rinne, M. 2000. Influence of the timing of the harvest of primary grass growth on herbage quality and subsequent digestion and performance in the ruminant animal. University of Helsinki, Department of Animal Science. Publications 54. 42 p. +5 encl. Academic dissertation. Available at: http://ethesis.helsinki.fi/julkaisut/maa/kotie/vk/rinne. 